\title{
PEQUeÑa Y MEDIANA EMPRESA EN EL MUNDO RURAL MEDIEVAL. FORMAS DE ORGANIZACIÓN DE LA PRODUCCIÓN. EJEMPlos DEL País VALENCIANO (SigLO XV)
}

\author{
ANTONI LLIBRER ESCRIG \\ Universitat de València
}

Recibido: 10 de febrero de 2020

Aceptado: 23 de abril de 2020

\begin{abstract}
Resumen
El presente estudio analiza el concepto empresa aplicado al periodo medieval, e intenta un mínimo recorrido historiográfico por aquellos autores que se han acercado a la «Business History». Además intenta una reconstrucción de los distintos tipos de empresa manufacturera en un ámbito rural que se nos muestra cada vez más dinámico, pero poco estudiado todavía por parte de los historiadores interesados en el mundo del artesanado y de la industria. Se estudian las distintas formas de organización de la producción que condicionan los diferentes modos de gestión de la empresa manufacturera tomando como referencia el espacio valenciano.
\end{abstract}

\section{Palabras clave}

Empresa, manufactura, artesanado, gestión, baja Edad Media, antiguo Reino de Valencia.

\section{Abstract}

This article analyses the concept of «enterprise» as applied to the medieval world and attempts a short historiographic review of those authors that have followed a Business History approach. Besides, it tries to reconstruct the different types of manufacturing enterprises in a rural world that seems more and more dynamic, although it is still under-researched by historians interested in industry and artisanship. Lastly, the different forms of organising production are analysed, which determine the various types of management of manufacturing enterprise in the Ancient Kingdom of Valencia.

\section{Keywords}

Enterprise, manufacture, artisan, management, Late Middle Ages, Kingdom of Valencia.

1 Departament d'Història Medieval. Facultat de Geografia i Història. Universitat de València. J.Antonio.Llibrer@uv.es. ORCID: http://orcid.org/0000-0002-1161-6594. 


\section{Resum}

El present treball analitza el concepte d'empresa aplicat al periode medieval, i intenta un mínim recorregut historigràfic per aquells autors que s'han apropat a l'anomenada «Business History». Alhora, intentem una reconstrucció dels distints tipus d'empresa manufacturera en un àmbit rural que se'ns mostra cada volta més dinàmic, però que els historiadors encara no han estudiat amb intensitat. Estudiem també les diferents formes d'organització de la producció que determinen els models de gestió de les empreses artesanals.

\section{Paraules clau}

Empresa, manufactura, artesà, gestió, baixa Edat Mitjana.

\section{Introducción. ¿Una historia de la empresa en época medieval?²}

Buena parte de la historiografía medieval todavía es hoy reticente a catalogar como «empresas» muchas iniciativas y realidades económicas llevadas a cabo en el ámbito urbano, en ciudades y villas con potentes y activos grupos emprendedores surgidos de la actividad mercantil o de la pluralidad de las formas industriales. Y todavía es más infrecuente -y algún lector dirá que imprudente- asignar el concepto «empresa» a determinadas iniciativas económicas que tuvieron como base el ámbito rural, el espacio de las pequeñas villas o comunidades que tradicionalmente entendemos como centradas en exclusiva en el trabajo de la tierra. Tales presupuestos de partida, o mejor, tales dudas de inicio, que compartirán muchos medievalistas, nos obligan a establecer una categorización conceptual adecuada, y un mínimo recorrido historiográfico, para llegar a entender que el concepto «empresa» no sólo no es un anacronismo, sino que resulta una categoría enormemente funcional y necesaria para definir muchas situaciones de organización productiva y mercantil en el mundo medieval urbano y rural, que además incluían realidades laborales, tecnológicas, contables y societarias muy variadas.

Hablar de empresa en la Europa preindustrial nos lleva a hacerlo con prudencia, por supuesto, pero con el convencimiento de que se trata de una categoría de análisis altamente operativa, y de la que debemos desvincular los conceptos que el mundo contemporáneo ha impuesto sobre dicha tipología. Las sociedades anónimas, los consorcios empresariales, los polígonos industriales, las multinacionales, la producción a gran escala, la publicidad y la mercadotecnia... son datos que tienden a condicionar nuestra percepción del hecho empresarial, y que nos hacen olvidar, por un lado, que la empresa también es otra cosa; y, por otro, que la empresa tiene una historia que va más allá del siglo XIX. Y es que las actuales estadísticas macroeconómicas sobre producción y mercado, nos dicen que el peso de las pequeñas y medianas empresas -las pymessigue siendo todavía hoy fundamental. No podemos limitar la empresa a los modelos de gestión en los que se produce un fuerte grado de integración vertical, con jerárquica

2 Este trabajo ha sido elaborado en el marco del proyecto Entreprises rurales en Méditerranée occidentale, XIIIe-XVe siècles (ERMO), 2014-2018, organizado por la Casa Velázquez de Madrid, Ecole des Autes Études Hispaniques et Ibériques, y coordinado por la profesora Catherine Verna (Université Paris 8). 
separación administrativo/productiva, con intensas economías de escala, con amplia diversificación laboral. La empresa así entendida nace tras el proceso de diferenciación socio-económica que tuvo lugar en Europa a partir del siglo XIX, y, sobre todo, en su segunda mitad, gracias a la generalización de los nuevos procesos de industrialización capitalista. Pero, como decíamos, la empresa tiene una historia previa al capitalismo, a la economía contemporánea, y por ello es necesario que atendamos a categorizar sus tipologías y sus formas precapitalistas.

Desde los trabajos de Armando Sapori o Federigo Melis en los cincuenta y sesenta, hasta los de Paolo Malanima, Philippe Brauntein o Catherine Verna, podríamos decir que parece crearse una mínima línea historiográfica que, de una manera u otra, ha entendido que la actividad económica bajomedieval se vertebraba, en muchas ocasiones, a través de formas empresariales más o menos complejas. Si bien es cierto que no podemos categorizar a todos los autores anteriores como «historiadores de la empresa», clasificación que, per se, no tiene demasiado sentido, sí es cierto que en sus investigaciones han puesto al descubierto estructuras organizativas, productivas, societarias y mercantiles que remiten a distintas formas empresariales de época preindustrial, y en concreto, de la baja Edad Media.

En la década de 1920, en el ámbito anglosajón, se configuró la denominada Business History, disciplina que pretendía el análisis individualizado de las formas y métodos empresariales, de sus tipos de gestión y de su impacto socioeconómico; tal disciplina incluía el estudio, que podríamos llamar ya «microhistórico», de empresas o compañías concretas, e incluso la reconstrucción de biografías (¿antecedente del análisis prosopográfico?) de empresarios, de emprendedores destacados o de otros operadores económicos. Inicialmente los trabajos de Norman S. Grass, fundador del Bulletin of the Business Historical Society ${ }^{3}$, desde la Harvard Business School, y sobre todo, los de Alfred Chandler, desde la misma universidad, iniciaron esta trayectoria historiográfica, pero que, desde el principio, quedó restringida esencialmente al mundo contemporáneo. La obra clave de Grass, Business and capitalism: An Introduction of Business History (1939), pero también la de Chandler, la conocida The Visible Hand: The Managerial Revolution in American Business (1977), aunque separadas por más de tres décadas, son toda una declaración de intenciones sobre el marco cronológico al que se restringía esta disciplina ${ }^{4}$.

Desde Italia, con los trabajos de los citados Sapori, Melis, de Roover y otros, el estudio de consorcios financieros o compañías individuales (en ocasiones complejas compañías mercantiles con una amplia ramificación de negocios) y el análisis de su gran volumen documental-contable, parecía llevar los parámetros y los objetivos de la recientemente creada Business History, al mundo medieval y modernos. Datini, Del Bene, Peruzzi,

\footnotetext{
Este Bulletin (1926-1954) dio paso, desde 1955, a la Business History Review, la publicación decana en este campo.

4 La obra de Chandler (traducción castellana de 1987), significó la formulación de la empresa «moderna» o «multiunitaria» (que no surgió antes de 1850) caracterizada por su intensa y coordinada función administrativa, Chandler, La mano visible, pp. 15-26.

5 No podemos olvidar algunas iniciativas clave, como las llevadas a cabo, de forma casi pionera, por Georges Espinas con, sobre todo, su Sire Jehan Boinebroke, patricien et drapier douaisien, 1933.
} 
Bardi, Alberti... son algunos ejemplos de estas polivalentes empresas que han sido estudiadas con detalle, y que nos muestran un amplio conjunto de estrategias, de gestión administrativa y contable, de diversificación de inversiones y de negocios ${ }^{6}$.

La historiografía italiana ha seguido posteriormente esta vía de análisis que podríamos relacionar con la historia de las organizaciones o formas de empresa, y no sólo para la producción textil lanera o sedera, también para otros sectores económicos. Ahí están los trabajos, entre otros, y para el periodo medieval, de Bruno Dini, Giuliano Pinto, Paolo Malanima o Franco Franceschi ${ }^{7}$. También en ámbito francés o en área de los Países Bajos se ha podido identificar un progresivo interés por la exploración de las diversas vías de gestión técnico-productiva. El trabajo de Espinas, ya citado, y, posteriormente, la interesante asociación que Germain Siscard realiza entre emprendimiento, sociedad empresarial y molinería, suponen un interesante punto de partida que abría posibilidades heurísticas posteriores ${ }^{8}$. Así parecen indicarlo las investigaciones de Mollat, Sosson, Arnoux, Bottin, Roch o Braunstein 9 . En muchos casos, el observatorio de tales propuestas han sido pequeñas villas o entornos rurales, que manifiestan un dinamismo económico y una influencia en los mercados comarcales y regionales que, en buena parte, desconocíamos ${ }^{10}$.

Tras este repaso, a título de ilustración general de una tendencia historiográfica, pero sin ánimo de mostrar la totalidad bibliográfica, podría pensarse que en ámbito hispánico no se ha participado de dicho interés, pero, por ejemplo, algunos trabajos de Ruiz Martín ${ }^{11}$ o Claude Carrére, y posteriormente los de Paulino Iradiel, Ricardo Córdoba o Germán Navarro Espinach ${ }^{12}$, por citar sólo unos pocos, muestran no sólo el inicio del interés por las formas de organización empresarial en las épocas medieval y moderna, también la

\footnotetext{
6 En este sentido, es muy interesante la revisión de Hunt The Medieval Super-Companies, esp. pp. 38120. El autor, siguiendo a De Roover, habla abiertamente de «medieval businessmen».

7 En 1990, la XXII Settimana di Studi di Prato se dedica precisamente a L'impresa. Industria, commercio, banca, secc. XIII-XVIII (edit. por Cavaciocchi en 1991), y muchas de sus ponencias ya muestran el interés historiográfico en las formas de gestión empresarial (véanse las aportaciones de McKendrik, Sosson, Aymard o Boone). Aportación bibliográfica amplia de los autores citados en Degrassi, L'economia artigiana, y una reciente actualización y puesta al día en FRANCESCHI, "Il mondo della produzione"; en realidad, la bibliografía de ese volumen, Il Medioevo, de la Storia de la Storia del lavoro in Italia, pp. 504-585, ofrece un recorrido completo.

8 SicARD, Aux origines des sociétés anonymes.

9 La reciente monografía de VERNA, L'industrie au village, pp. 503-537, ofrece también una detallada bibliografía, y un interesante itinerario historiográfico.

10 Dos referentes bibliográficos, de sendas jornadas de Flaran, deben destacarse para este ámbito: L'artisan au village dans l'Europe médiévale et moderne (celebrado en 1997 y editado en 2000), y Les industries rurales dans l'Europa médiévale et moderne (2013).

11 En 1959, para referirse a la organización de las empresas de explotación del alumbre murciano, Ruiz Martín, no dudaba de hablar de cártel y trust, entre otras complejas estrategias corporativas, RUIZ MARTíN, Los alumbres españoles; CARRÉRE, "Structures et évolution des entreprises pré-industrielles", pp. 37-57.

12 Desde la obra referencial de IrAdiel, Evolución de la industria textil, a los trabajos más recientes de CórdobA, "Industria y artesanía rural"; Los oficios medievales; o de NAVARRo EsPINACH, "Los sectores punta de la industria rural", hay ya un cierto recorrido que no hace sino mostrar el interés actual hacia las formas de organización en un ámbito rural que se muestra dinámico.
} 
concreción y el asentamiento de modelos de análisis que, cercanos a la construcción prosopográfica, y con la combinación de fuentes privadas (notariales esencialmente) y públicas (ordenancistas, municipales o judiciales), permiten un acercamiento sistemático a la realidad de la producción y, sobre todo, de la gestión industrial y mercantil. Sin duda, este atractivo patrón de análisis continúa su desarrollo y su regionalización, llegando a la posibilidad de ofrecer ya no sólo una visión del trabajo en el ámbito de los grandes centros urbanos ${ }^{13}$, sino también de áreas rurales tremendamente dinámicas y dinamizadoras ${ }^{14}$.

A pesar de las variantes regionales, de las particularidades locales e incluso de las diferencias cronológicas de las investigaciones e iniciativas citadas, es cierto que todas nos hablan de formas de gestión, de modalidades organizativas, de prácticas laborales, de capacidades técnicas, de relaciones con el mercado, de experiencias empresariales en definitiva. En buena parte de estos trabajos se trasluce el objetivo de llegar a mostrar la empresa no sólo como un centro o una unidad de producción, y de organización de dicha producción, también como un núcleo de formación y de circulación del saber técnico, como un eje capaz de gestionar distintas vías de negocio y cierta diversificación, como una entidad que puede integrar o coordinar distintas fases de un proceso o de varios procesos productivos, e incluso con capacidad de penetración y actuación de forma directa en el mercado. Tal vez por todo este conjunto de capacidades, y toda esta complejidad, es tan interesante que hablemos de empresas, o de unidades empresariales, o de estructuras de empresa, también para las épocas medieval y moderna.

Lo que proponemos y reivindicamos -esto es, la consideración y la reconstrucción de las formas de empresa en el mundo rural bajomedieval-, no consiste en un simple cambio de terminología, denominando ahora como «empresas» lo que antes llamábamos «unidades de producción» o «células productivas»; tampoco nuestro objetivo es «finalista», es decir, la variedad de las experiencias empresariales de inversión, gestión y negocio, mostradas por las investigaciones indicadas, no pueden ser vistas ni interpretadas como simples precedentes de la empresa contemporánea. Lo que pretendemos es llevar a cabo una reflexión sobre la naturaleza, la tipología y el rol de la empresa en su mismo marco y su mismo contexto bajomedieval, destacando su función de nexo entre diversas formas e iniciativas productivas, mano de obra y saber técnico. La idea

\footnotetext{
13 Navarro Espinach, "Estudios sobre industria y artesanado", pp. 2-10; Iradiel, "Ciudades, comercio y economía artesana”, pp. 603-658; Córdoba, Los oficios medievales; Menjot, "El mundo del artesanado y la industria en las ciudades", pp. 5-18.

14 Por solo citar el empuje que el estudio de la empresa rural ha tenido en el espacio de la Corona de Aragón, dada ya la enorme nómina bibliográfica a través de la multitud de estudios de historia local, véanse, para el País Valenciano, los trabajos de Aparici MARTí, Producció manufacturera i comerç a Vilareal; Manufacturas rurales y comercio interior valenciano; y El Alto Palancia como polo de desarrollo económico; para las comarcas centrales destaca el trabajo de MARTínez Araque, En els orígens de la indústria rural; y en espacio de las comarcas del sur, los de LLIBRER, Los orígenes de la industria de la lana; y también Industria textil y crecimiento regional. La industria rural en el ámbito de la Corona de Aragón cuenta ya con algún interesante trabajo de síntesis, como el ya citado de NAVARRo EsPINACH, "Les industries rurales dans la Couronne d'Aragon", pp. 89-112.
} 
es que podamos analizar y entender mejor las realidades de producción manufacturera en ámbito rural donde, desde hace una decena de años, hemos comenzado a descubrir iniciativas y procesos en distintos sectores que traslucen nuevas formas de gestión y ciertos cambios en la producción, el trabajo y la comercialización de bienes de consumo en mercados internos y regionales.

\section{Una definición y un método de análisis}

Investigaciones de autores diversos - Braunstein, Verna, Córdoba de la Llave o Navarro Espinach-, tienden a considerar lógico y legímito el uso del concepto de «industria» aplicado al mundo rural en la baja Edad Media, en la medida que ciertas formas productivas llevadas a cabo en este marco posibilitaron satisfacer demandas exteriores -comarcales, regionales o internacionales, y demandas sostenidas en el tiempo-, con niveles de calidad media y elevada ${ }^{15}$, con estándares técnicos que exigían especialización y adaptación de nuevas capacidades técnicas asociadas a economías de escala, y que a su vez también exigían formas nuevas de gestión y administración (del capital fijo, del circulante, incluso de los rendimientos del capital humano, y de otras variables). Todas estas características no hacen sino recordarnos la necesaria capacidad de organización y el sentido de racionalidad que nos remiten de nuevo al concepto de empresa.

En este sentido, se ha llegado a distinguir, en periodos precapitalistas, entre «industria extensiva» asociada únicamente a parámetros cuantitativos, a la multiplicación de las unidades de producción; y, por otro lado, «industria intensiva», asociada a un aumento de la productividad por parámetros de aplicación de nuevas tecnologías, nuevas formas de organización y nuevos sistemas de gestión ${ }^{16}$. Este sería el caso de las «industrias» rurales de la baja medievalidad que no harán sino aprovechar las nuevas infraestructuras relacionadas con la generalización de la energía hidráulica y la configuración de colectivos emprendedores - nacidos no sólo del mercado sino también de la propia actividad manufacturera- que aportaban, junto al capital necesario para implementar las nuevas tecnologías, la capacidad de gestión de los ciclos artesanales amplios que exigían poner en contacto recursos, especialistas y profesionales diversos. Ante estas nuevas condiciones, era posible ya la aparición de economías de escala que mantuvieran

15 En la introducción de su última monografía, Catherine Verna definía con claridad tales diferencias, tales parámetros, que reproducimos por lo que tienen de programáticas: L'industrie est capable de livrer une production quantitativement importante, régulière, de qualité constante et reconnue sur le marché, une production qui dépasse le marché local [...]. C'est l'ampleur et la qualité du marché qui permettent de définir comme «industriel» un secteur de production médieval, VERNA, L'industrie au village, p. 18. En este sentido, véanse también las consideraciones iniciales de Poussou, Jean-Pierre, "Les industries rurales dans le sud-ouest de la France”, pp. 223-226. También son fundamentales las bases que la autora establece en Verna, "Entreprises rurales en Méditerranée occidentale”, pp. 203-220.

16 Verna, L'industrie au village, pp. 789-812 (citando a Pelet, “Une industrie bimillénaire”). No obstante, los planteamientos de TiLly, "Flows of capital", circulan, en parte, por la misma dirección, entendiendo que la multiplicación de pequeñas unidades de producción estaba en la base de un posterior desarrollo industrial. 
las demandas continuadas de los mercados comarcales y regionales. Y podríamos decir que estas son sin duda las características de la «industria» en ámbito rural antes de la revolución industrial ${ }^{17}$.

Para este marco, es necesario acercarnos a una definición adecuada del concepto «empresa». Paolo Malanima entiende que es clave reflexionar y reformular dicho concepto atendiendo precisamente a los parámetros económicos propios de las sociedades preindustriales. En este sentido, el profesor italiano justifica que, desde un nivel de análisis microeconómico (más acorde a los procesos previos al crecimiento contemporáneo, y a las posibilidades que las misma fuentes del periodo propician), la «empresa» debe definirse como el organismo en el que se combinan factores de producción para ser transformados en bienes económicos: l'istituzione in cui vengono combinati i fattori della produzione - o input-con il fine de transformarli in beni economici-merci (anche semilavorativi) e servizi- pronti per il consumo da parte de individui o di altre imprese ${ }^{18}$.

Pero para iniciar un acercamiento a las formas de empresa es necesario remitir a una opción metodológica y heurística que encuadre (y justifique) la propuesta de este trabajo. Ya hemos hablado de la necesidad de una visión microhistórica para esta aproximación. Uno de los principales problemas que tiene el investigador que pretende reconstruir empresas en el mundo rural medieval radica en el hecho de que no todos los elementos que tienen un rol relevante en una determinada situación, acción o decisión económica, nos parecen abiertamente en las fuentes, y no son por ello fácilmente mesurables ni cuantificables $^{19}$. Y precisamente estos aspectos no mesurables ni observables de forma directa son, en ocasiones, relevantes a la hora de comprender los mecanismos que operan en un determinado contexto económico. Es por ello que surge la necesidad de implementar el método prosopográfico en este acercamiento a la realidad económica ${ }^{20}$. No se trata ahora de descubrir las virtudes de la prosopografía en la història económica, pero sí de incidir en la idoneidad de su aplicación para un acercameinto certero a las

\footnotetext{
17 Braunstein, Travail et entreprise au Moyen Âge; NAVArro Espinach, "Los sectores punta de la industria rural"; CóRdoba de LA Llave, "Industria y artesanía rural”, pp. 37-39.

18 Malanima, "Tipi d'impresa", pp. 160-161. Verna completa la definición indicando que el contacto con el mercado resulta clave, pero en el sentido que éste propicia la asunción de cierto sentido de negocio por beneficio. El matiz es muy interesante y debe tenerse en cuenta: pour qu'une unité de production pisse étre qualifiée d'entreprise au Moyn Âge, il faut, je crois, et cela peut donner matière à de débat,qu'elle ait un objectif principal qui, même s'il n'est pas déclaré ouvertement dans les sources, peut être repéré dans les pratiques que restituent ces sources: réaliser des gains; dégager des bénéfices dans un contexte de concurrence que l'ouverture sur le marché établit de facto, VERNA, "Quelles sources pour quelles entreprises, pp. 341-343; sigue la tesis de Braunstein que afirma claramente que para los siglos XIV y XV, l'un des moteurs de l'entreprise est le calcul du profit, BRAunsteIn, "Les métiers du métal", 23-24. Estos matices no hacen sino confirmar la dificultad de definir esto que llamamos la «empresa preindustrial»; pensemos que está en relación no únicamente con diversas necesidades económicas (consumo, demanda, trabajo, tecnología), también con otros elementos y valores sociales e incluso culturales o religiosos (la usura y los condicionantes del crédito, por ejemplo, o la valoración del trabajo «manual» frente a otras actividades de distinto rago social, etc.).

19 Sobre tales puntos metodológicos de partida, FAVEro, "Microstoria e storia economica", pp. 107-117.

20 La prosopografía ha demostrado su validez, y ha merecido ya espacios de reflexión, IRADIEL, "Fuentes de derecho privado: protocolos notariales e historia económica”, pp. 225-247.
} 
formas de organización y gestión de la producción, y a la realidad de eso que estamos llamando estructuras incipientes de empresa. Así, las prosopografías no sólo permiten descubrir un frame, es decir, una situación dada en un momento dado, sino que posibilitan observar comportamientos económicos en periodos mayores, en contextos temporales amplios, de años o décadas, con la evolución de las actividades y los negocios, de las estrategias económicas y también sociales ${ }^{21}$.

Con las prudencias necesarias, se trata ahora de realizar un primer acercamiento a la tipología de empresa en ambito rural mediante las posibilidades que la documentación aporta en el espacio de la Corona de Aragón, y el ámbito valenciano, en el contexto del siglo $\mathrm{XV}$, momento elegido en función del crecimiento reconocido de las actividades manufactureras en muy diferentes sectores y actividades. El aumento de la demanda -rural y urbana- que explica tal desarrollo se entiende como un indicador más de la recuperación económica tras la crisis bajomedieval. La disponibilidad de capitales en grado de crear demanda de bienes de consumo de calidades medias y altas, junto a la configuación de sectores emprendedores aptos para satisfacer dichas demandas son fenómenos no sólo típicos del mundo urbano. Amplios sectores de la población campesina pasaron a ser potenciales consumidores de productos con ciertos estándares de calidad. Los espacios rurales conocieron, en este periodo, una estratificación social y una pluralidad de ocupaciones, profesiones y oficios no conocidos antes ${ }^{22}$. Las fuentes de ámbito rural, que en buena parte están siendo explotadas desde hace pocos años, no dejan de mostrar un interesante dinamismo económico, industrial, manufacturero y «empresarial» que debemos comenzar a interpretar.

\section{Panorama de los tipos de empresa manufacturera en el mundo rural bajome- dieval. Categorizar la producción}

Antes de intentar una aproximación a los diferentes tipos empresariales, sería interesante incidir en un punto común (independientemente de la escala de análisis, y del sector), es el que refería a los cuatro tipos de «gestión» que debía afrontar toda empresa, y que la determinaba desde su origen, independientemente de número de trabajadores, actividad, especialización interna, etc. En primer lugar, la gestión que tenía que ver con el hecho mismo de la producción con todas sus implicaciones: consecución de los inputs necesarios (materias primas, tecnología básica, instalaciones), control de los tiempos y los espacios en función de ritmos marcados por condiciones internas y externas...; en segundo lugar, y en lógica relación con la anterior, era necesaria una gestión de la mano de obra que integraba la producción, de sus diferentes niveles de especialización,

\footnotetext{
21 El concepto de frame como punto de observación en FAVERo, "Microstoria e storia economica", pp. 111-113; por otro lado, sobre la observación combinada de estrategias económicas y sociales (cambio de rol, mobilidad, promoción social, cambio de negocio, pluriactividad), y como buenos modelos de análisis, Scherman, Familles et travail à Trévise, y también Pfirsch, Thomas, "Artisans et pluriactivité", pp. 5-22. 22 En este sentido, y como una adecuada contextualización general (que no podemos desarrollar o detallar aquí), NAVArRo Espinach, "Los sectores punta de la industria rural”, pp. 175-179.
} 
de su complementariedad, de sus formas de dedicación laboral (total o parcial), de los ya indicados tiempos de trabajo, de las posibles formas de remuneración; la tercera gestión era la derivada de las formas de financiación, de las inversiones necesarias (en capital fijo o circulante), de la dinámica del crédito y la deuda, que condicionaban los niveles de producción, y que generaban interesantes formas asociativas entre artesanos y operadores; finalmente, como ya indicábamos, en la empresa era fundamental un último tipo de gestión, la que refería a las relaciones con el mercado, a su acceso directo (o indirecto), a su conocimiento, al conocimiento de la demanda, a los modos de circulación de los productos elaborados y semielaborados (mediante el contacto con profesionales del mercado y el transporte), y, sobre todo, la que refería a la fijación de los precios ${ }^{23}$. En definitiva, este sencillo repaso a las necesidades de gestión de una empresa nos habla ya, no sólo de su complejidad interna, también de la exigencia de un mínimo conocimiento y una mínima dedicación a los aspectos administrativos y organizativos.

\subsection{Empresa simple o individual}

Asumida ya la complejidad inherente a la unidad empresarial, podemos iniciar una sencilla distinción tipológica, distinción de los modelos productivos, aunque, como ya indicábamos, son difíciles de separar las difusas líneas que pueden diferenciarlos. En este sentido, el primero de los elementos que puede ayudarnos a establecer estos modelos de organización es el que refiere a la autononía productiva del artesano, es decir, al rol del artesano como «independiente», a la «independencia» en su taller; eso que se ha dado en definir «artesano propio» o «puro», propietario de los medios de producción, que trabaja en su taller gracias a la consecución de un saber técnico, y para obtener un producto comercializable ${ }^{24}$. Esta definición, que resulta ya clásica, nos lleva a un primer modelo, a un primer tipo empresarial, que podríamos llamar, «empresa simple o individual», como ha indicado ya algún autor $^{25}$, caracterizada por la presencia del artesano-especialista como cabeza y organizador de la producción en el taller, de forma directa y autónoma. Innumerables carpinteros, zapateros, sastres, herreros, pintores, orfebres, etc., que se encuentran con tanta facilidad en la documentación rural, podían configurar este grupo de pequeños artesanos empresarios, que eran propietarios de su espacio de trabajo, de sus instrumentos, así como de los productos que elaboraban. Su relación con el mercado les podía obligar con frecuencia a recurrir al servicio de mer-

\footnotetext{
23 Sobre estas necesarias «gestiones» de la empresa preindustrial, VerNA, "Quelles sources pour quelles entreprises", pp. 342-343.

24 Sobre la definición -o definiciones- de artesano o, mejor dicho, de este modelo artesanal, Degrassi, L'economia artigiana, pp. 12-14; BraUnSTEIn, "Artesano", p. 65; y especialemnte FranCESCHI, "Il mondo della produzione", pp. 374-377. No somos ajenos al debate que, desde hace una década, se plantea en relación a la citada «autonomía» artesanal, y especialmente en el juego de roles que genera la aparición en el mundo urbano (y en mucha menor medida en ámbito rural) de las corporaciones de oficio. Sólo dos ejemplos recientes de los puntos y la bibliografía de tal debate, BERNARDI, Maître, valet et apprenti au Moyen Âge; y Caracausi, Davies, Mocarelli (eds.), Between Regulation and Freedom, esp. cap. 4, pp. 65-86.

25 Pratesi, "Il lavoro contrattato", pp. 9-31.
} 
caderes o intermediarios para abastecerse de determinadas materias, pero la relación que les ligaba con estos operadores podía ser externa a su taller y a las actividades en él desarrolladas, que seguían siendo gestionadas completamente por los artesanos ${ }^{26}$.

A pesar de la limitación de las fuentes en ámbito rural, el investigador encuentra algunos indicios que le permiten individualizar este primer colectivo empresarial, y los análisis prosopográficos ayudan a ello: la propiedad del obrador o la botiga, la adquisición en el mercado de todo tipo de materias primas o productos semielaborados, operaciones de compra anticipada de esos mismos inputs, la inversión en tecnología o instalaciones productivas, la presencia de algún ayudante o aprendiz, la propiedad de animales de carga, la venta directa a consumidores de sus bienes producidos, la búsqueda de crédito o su deuda posterior, la participación en sociedades o compañías con otros operadores, incluso el acuerdo de un matrimonio estratégico con miembros del mismo sector buscando la continuidad o la ampliación del negocio familiar ${ }^{27}$. Tal sería el perfil económico y social de estos colectivos, $\mathrm{y}$, aunque es cierto que la documentación no siempre ofrece todos estos detalles, el paso de los artesanos por la mesa de los notarios o de los oficiales de la administración municipal, nos permite descubrir tales características.

Por sólo citar algunos ejemplos que han sido prosopografiados y estudiados, numerosos carpinteros de Alzira en el siglo XV, donde se configuró una interesante concentración de este sector artesanal desde finales de la centuria anterior ${ }^{28}$; también muchos herreros, zapateros, albarderos, tanto cristianos como musulmanes... de Segorbe y su comarca; o de la zona de la Plana de Castelló, que aparecen como propietarios de sus talleres, y llevando a cabo los negocios citados ${ }^{29}$; sastres, zapateros y todo tipo de profesionales del cuero y la piel en Cocentaina, Ontinyent, Albaida o Bocairent ${ }^{30}$; innumerables jaboneros de Elx y su comarca ${ }^{31}$; herreros, carpinteros y curtidores de todo tipo que Verna proposografía en las comunidades del Pirieno catalán, son sólo algunos ejemplos de las actividades y los negocios de muchas de estas pequeñas empresas rurales que producían y trabajaban para los mercados comarcales y regionales ${ }^{32}$.

\footnotetext{
26 FranCESCHI, "Il mondo della produzione", pp. 374-381.

27 Aunque no es específicamente el objetivo de este ensayo, es necesario integrar ya, en el estudio de la empresa manufacturera -urbana y rural-, la función de la mujer, y no sólo como sujeto socioproductivo, también como agente de gestión empresarial, IRADIEL, "Familia y función económica de la mujer en actividades no agrarias", pp. 223-259; ZANOBONI, "De suo labore et mercede me adiuvavit", pp. 103-121.

28 Martínez Araque, En els orígens de la indústria rural, pp. 102-114.

29 Igual y Navarro, "Artesanos y mercaderes"; Aparici Martí, Producció manufacturera $i$ comerç a Vila-real; ApARICI Martí, Manufacturas rurales y comercio interior valenciano; ApARICI MARTí, El Alto Palancia como polo de desarrollo económico; APARICI MARTí, "Emigración y trabajo en el siglo XV"; ApArici Martí, "La promoció social dels artesans"; Aparici MArTí, "Pieles, zapateros, curtidurías"; Iradiel et alii, Oficios artesanales y comercio en Castelló de la Plana; NAVArRo, La industria del cuero en el Reino de Valencia. En relación, de forma específica, al artesanado mudéjar: IguAl, Llibrer y NAVARRo, "Materias primas y manufacturas textiles en las aljamas rurales"; HinoJosA, "El trabajo mudéjar en la Valencia medieval"; APARICI, "Manufactures rurals mudèjars"; LLIBrER, "Dualidad en la aljama".

30 LLIBRER, Industria textil y crecimiento regional, pp. 221-263.

31 Serrano, "Desenvolupament i destrucció d'una minoria”, pp. 62-72; Hinojosa, "La industria en Elche a fines de la Edad Media".

32 VERnA, L'industrie au village, pp. 90-120.
} 
Dos aspectos de su perfil socioprofesional deben ser destacados. Por un lado, su acercamiento y presencia en el mercado, y no sólo para la venta de los bienes acabados, también para redistribuir todo tipo de materias primas e incluso todo tipo de productos agrícolas (cereales, vino, aceite, carne, pieles...); hasta tal punto esta función mercantil está presente en sus empresas, que con frecuencia son denominados también en la documentación como «tenderos», «botiguers», y en algunos casos como «mercaderes». Si bien tales designaciones son muchas veces coyunturales en las fuentes ${ }^{33}$, al menos están indicándonos estrategias y vías de negocio de estas empresas ${ }^{34}$.

Por otro, es también interesante en estas empresas la búsqueda del asociacionismo para propiciar el fomento de su actividad y para aumentar la eficiencia. Por poco que uno frecuente la documentación notarial de villas y comunidades (aunque también otros registros), se habrá topado con referencias a «societats o companyies» integradas por distintos operadores (artesanos, mercaderes, tenderos, notarios...). En el mundo rural, donde la configuración de un entramado confraternal y corporativo está aún prácticamente ausente, estas asociaciones temporales permitían un sorpendente juego de relaciones. Sin embargo, mucho más allá de generar posibles contactos, lo que nos importa de tales sociedades es el conjunto de negocios y redes económicas que trazan. En primer lugar, conviene recordar que encontramos esencialmente dos tipos de asociaciones, o formas societarias: la denominada «paritética», compuesta por profesionales del mismo oficio que aportaban capitales, instalaciones, tecnología o instrumental para iniciar un negocio común durante un periodo muy concreto; y una segunda variante, caracterizada por la «asimetría», en la medida que estaba integrada por un sector artesanal (uno o más artesanos) y un sector financiador (uno o más socios que aportaban capital para el nuevo negocio común, y que solían gestionar su administración) ${ }^{35}$.

Unir fuerzas y repartir los costes en el taller y otras instalaciones permitía el incremento del volumen de negocio en determinadas coyunturas. Además facilitaba crear redes de

\footnotetext{
33 Llibrer, "Artesanos emprendedores", pp. 295-317; Llibrer, Industria textil y crecimiento regional, pp. 148-152; Aparici Martí, El Alto Palancia como polo de desarrollo económico; Verna, L'industrie au village, pp. 139-150.

34 Con la elaboración de los análisis prosopográficos para nuestro proyecto doctoral, comenzamos a obervar la dedicación «mercantil» de una buena parte de los artesanos rurales documentados. Su interés por la compraventa de cereales, de vino, de aceite, de ganado de todo tipo, incluso de animales de tiro, también de carne, de pieles, etc. les llevaba a una presencia constante en el mercado, a la compra previa (en ocasiones a adquisiciones anticipadas a crédito antes de las cosechas) para su venta posterior a mejor precio, en el mercado comarcal y supracomarcal, véase vol. II de nuestra tesis doctoral, LLIBRER, Industria textil y crecimiento regional; y también LLIBRER, "Llana, ramat i oli", pp. 63-79. Pero esta vocación mercantil ha sido documentada también en otras àreas de importante desarrollo manufacturero rural, hasta el punto de que puede ser considerada como un rasgo de estas empresas artesanales (véanse trabajos de la nota anterior). Su visión y conocimiento del mercado de sus comarcas (por la necesidad de abastecimiento de sus inputs industriales), les lleva a abrir una interesante vía de negocio.

35 Sobre estas tipologías, Caracausi, "Tipos de empresa en el periodo preindustrial", pp. 2-9; Demo, L'anima delle città, pp. 110-137; BARLUCCHI, "Industria e artigianato", pp. 262-264; FrANCESCHI, "Il mondo della produzione", pp. 377-381; LLIBRER, "La formación de compañías", pp. 59-72; LliBRER, "Empreses i empresaris en àmbit rural", pp. 61-74. También es necesaria la consulta de BonACHİA y CARVAJAL, Los negocios del hombre.
} 
trabajo e intercambio entre profesionales de distintas capacidades y niveles de empresa. La reducida duración de tales formas societarias (normalmente un año) permitía que la asunción de riesgos fuera también limitada. En definitiva, estas sociedades o compañías de capital y trabajo eran altamente operativas y adaptables a cualquier nivel de inversión y a todo tipo de sectores manufactureros. Las encontramos para el fomento de la producción de paños, y para facilitar su tintado y su venta posterior ${ }^{36}$; también para el transporte de madera y el trabajo del sector de la carpintería ${ }^{37}$; para impulsar la producción y la comercialización de centenares de piezas de cerámica de muy distinta tipología ${ }^{38}$; para la elaboración y distribución de complementos para la construcción (azulejos, pavimentos, tejas) ${ }^{39}$; para promover el trabajo en las canteras y transportar sillares y todo tipo de materiales hasta las construcciones públicas y privadas ${ }^{40}$; para el montaje de fraguas y la transformación de los metales pesados... ${ }^{41}$ Las posibilidades y la puesta en práctica de estas formas societarias nos llevan ya en parte hacia otro tipo de empresas de mayores iniciativas y diversas formas de producción.

\subsection{Empresa de unidades diseminadas. Manufactura descentralizada}

Resulta evidente que la empresa artesanal individual (asociada al profesional, cabeza, director y patrono de su propio taller, auxiliado por los miembros de su familia y algún mozo o aprendiz), gestionada de manera autónoma, y que operaba en contacto directo con el mercado y los consumidores, no resultaba suficiente para el desarrollo en determinados sectores productivos (y sectores, por otro lado, de enorme trascendencia en el mundo medieval). Por ejemplo, la producción textil -lana, seda e incluso algodón-, o, en ocasiones, el curtido de pieles, o la más específica de elaboración de armas y armaduras, exigían una nueva solución organizativa en la medida que generaban un elevado número de diferentes operaciones y trabajos consecutivos, con distintos profesionales, medios e instalaciones. A su vez, este fraccionamiento del proceso tecnológico debía llevarse a cabo en una serie de espacios operativos distintos y dispersos; en talleres, pero también a domicilio (en viviendas de trabajadores y trabajadoras auxiliares), y en otras instalaciones que, por su teconolgía o por el uso de determinadas formas de energía, se ubicaban en espacios muy dispares. El ejemplo de la pañería resulta significativo para entender tal dispersión de trabajo, tecnología e iniciativa: desde los lavaderos donde la lana era tratada y seleccionada (cerca de cursos y ríos), al ámbito doméstico donde un ejército de cardadores, hiladoras y urdidores preparaban la fibra para que el

\footnotetext{
36 Llibrer, "La formación de compañías", pp. 59-72; Llibrer, "Empreses i empresaris en àmbit rural”, pp. 61-74.

37 Martínez Araque, En els orígens de la indústria rural, pp. 102-114.

38 Llibren, "Relaciones protoindustriales en la producción cerámica", pp. 214-240.

39 García Marsilla e IzQuierdo Aranda, Abastecer la obra gótica, pp. 49-70.

40 Llibrer, Godella, una comunidad rural en la baja Edad Media, Ajuntament de Godella, Valencia, 1996, pp. 45-90; NAVARro, "La historia de la construcción en los países de la Corona de Aragón"; MonTERO, "Moro Petit: los trabajos de un picapedrero musulmán”, pp. 27-39.

41 VERnA, L'industrie au village, pp. 299-331.
} 
tejedor, en su taller, pudiera poner en marcha su telar; del obrador del pelaire al patio del tirador donde el paño era cardado; del molino batán donde se le daba consistencia al taller del tundidor para fijarle la textura adecuada; y de allí a la tintorería (proceso que podía hacerse también antes del tejido) para procurarle el valor merceológico que exigía el consumidor.

Este ejemplo de la elaboración de la lana, ya bien conocido, no es sino un testimonio claro de esta opción productiva que requería una nueva solución organizativa $\mathrm{o}$ empresarial: pensemos, en primer lugar, en la necesidad de la figura de un operador que gestionara y coordinara las numerosas fases y trabajadores/as implicados; pensemos también en las inversiones constantes que suponían el mantenimiento de las diversas instalaciones, su tecnología, las materias primas, etc.; y en tercer lugar, recordemos la disparidad de mano de obra implicada y la dificultad de su gestión: desde profesionales de elevado saber técnico y catalogación (como los tintoreros o los pelaires), a las trabajadoras y trabajadores domésticos de escasa cualificación pero imprescindibles; no olvidemos, a su vez, que entre todo este conjunto laboral encontramos diferentes grados de iniciativa y de autonomía.

Se ha hablado normalmente de la figura del mercader-empresario como el operador que tendía a poner en marcha este modelo de producción configurando una amplia empresa que incluía y enlazaba buena parte - $\mathrm{o}$ en ocasiones el total- de las operaciones para la elaboración de las mercaderías. Con elevada capacidad de inversión, adquiría las materias primas para después distribuirlas entre los obradores domésticos o los talleres, coordinaba el paso de los semielaborados o los insumos de una fase a otra, gestionaba también (o incluso poseía) las infraestructuras técnicas (batanes, hornos, curtidurías, almazaras, tiradores, talleres, tintorerías...), e implementaba el trabajo por encargo, a parte de ocuparse de la comercialización de los bienes producidos. El poder del capital mercantil, y su penetración en la esfera de la producción, permitió la configuración de estas empresas de talleres y artesanos diseminados, y dio lugar a un amplio desarrollo de la industria bajomedieval y moderna, que la historiografía ha destacado desde hace décadas ${ }^{42}$.

Pero no siempre se ha destacado la capacidad de determinados artesanos emprendedores para llevar a cabo esa misma gestión de las fases productivas, y de configurar estas empresas de talleres diseminados con los artesanos dependientes o de fase. Es decir, desde el mismo sector de la producción, y esto fue realmente importante en áreas rurales, nacieron también estas iniciativas, y con resultados que generaron auténticas concentraciones manufactureras especializadas en ciertos sectores de bienes de consu-

\footnotetext{
42 Ya hemos hecho referencia a los trabajos de Melis y otros autores coetáneos y posteriores. Como interesantes síntesis actuales, FranCESCHI, "L'impresa mercantile-industriale", pp. 229-249; FranCesChI, "Il mondo della produzione", pp. 374-420; LANARO, "Il mercante e l'imprenditore", pp. 209-216; BARLuCCHI, "Industria e artigianato", pp. 248-275; CARACAUSI, "Mercanti e manifatture tessili", pp. 19-31; AMmannati, "L'opifici lanieri di Francesco di Marco Datini”, pp. 497-523; y en el ámbito peninsular, Iradiel, Evolución de la industria textil; IRADIEL, "En el Mediterráneo occidental peninsular"; IRADIEL, "Ciudades, comercio y economía artesana", pp. 603-658; IRADIEL, "Metrópolis y hombres de negocios”, pp. 277-310.
} 
mo. Nuestra idea es recordar que no sólo el capital mercantil, sino también el mismo capital industrial fue capaz de articular estos mismos modelos de producción y de empresa. La dinamicidad del mundo rural bajomedieval, que estamos conociendo desde hace pocos años, nos permite localizar y documentar muchos emprendedores que han surgido de los mismos sectores productivos, y que van articulado poco a poco una vía de crecimiento de las actividades manufactureras. Ante esos ciclos de trabajo o ciclos tecnológicos muy fraccionados, con elevado número de operaciones, estos artesanos comenzaron a asumir la función del «hacer trabajar», del faciunt laborare, ${ }^{43}$ del trabajo por encargo para que el ciclo fuera avanzando y completando sus fases; su capacidad de inversión le permitía coordinar y organizar el trabajo desde dentro del mismo proceso productivo. Anticipaban las materias primas, y, tras el trabajo encargado, asumían la remuneración a cada colaborador, mientras se reservaba la propiedad del producto final. Por ello, ante la tan diversificada oferta de la mano de obra (con actores y profesionales tan dispares), la característica clave que definía a estos artesanos emprendedores era la de su importante capacidad laboral, es decir, la capacidad para «hacer trabajar», para coordinar numerosas habilidades y especializaciones dispersas y ramificadas.

A nadie se le escapa que tal modelo productivo remite al ya conocido Putting-out-system, el régimen de trabajo a domicilio por encargo del comerciante empresario, que acaba generando situaciones de dependencia y dominio de la iniciativa mercantil sobre la industrial. Sin tratar de cuestionar el modelo de explicación protoindustrial, es evidente que el carácter emprendedor del colectivo de los verlegers se hizo patente también en muchos artesanos empresarios. Partir de la producción, es decir, que el coordinador o gestor sea uno de los artesanos que laboraban en el ciclo no sólo supone un cambio conceptual teórico, suponía dar valor al saber técnico, al conocimiento de todos los detalles prácticos, y al contacto previo con otros profesionales complementarios del sector, para posteriormente facilitar el paso a la función de enlace y coordinación. No es casual, en este sentido, que muchos artesanos que suscribían sociedades o compañías de trabajo y capital, desarrollaran posteriormente estas tareas de gestión de los ciclos productivos fragmentados ${ }^{44}$.

Otro punto fundamental que tratar es entender por qué un activo artesano llegaba a convertirse en empresario gestor o coordinador, y numerosas son las causas que llevaban a ello. Su misma cercanía a la producción y a sus secretos, pero también su cercanía a las materias primas y al resto de inputs que permitían el ciclo tecnológico, el contacto con otros artesanos, el conocimiento de familias dispuestas al trabajo a domicilio, la capacidad de inversión y el contacto con el mercado, son rasgos que los definían, como veremos, y que explican su rol de gestión. Pensemos que tales artesanos emprendedores nacían en muchas ocasiones, como hemos observado también, de los sectores más poderosos del mundo rural, de las familias campesinas acomodadas, con

\footnotetext{
43 La expresión es retomada por MocARelli, "Fare impresa in età preindustriale", pp. 209-227; y por LANARO, "Il mercante e l'imprenditore", p. 213.

44 NaVArro, "Los negocios de la burguesía en la industria precapitalista"; Llibrer, "La formación de compañías", pp. 59-72; LliBrer, "Empreses i empresaris en àmbit rural”, pp. 61-74; VerNA, "Elites rurales, industries et fortune”, pp. 461-478; VERNA, "Pour une approche biographique des entrepreneurs”, pp. 77-88.
} 
amplio patrimonio inmueble (y en ocasiones tecnológico que incluía molinos, almazaras, hornos, carnicerías...), con amplia tradición familiar en la comercialización de todo tipo de productos agrícolas, de amplia participación favorable en el mercado de capitales a través del crédtiro censal, de destacada presencia en los órganos de control comunal, en las instituciones locales y en los resortes del poder feudal (gestionando todo tipo de monopolios o impuestos...). En definitiva, estos rasgos de los sectores acomodados rurales son también características que distinguiremos en los artesanos emprendedores. $\mathrm{Y}$ es que se trata ahora de que expongamos casos concretos, surgidos a la luz de la documentación, de este trascendente sector artesanal para facilitar su comprensión. Vamos a una amplia zona, ya conocida, de las comarcas del sur valenciano donde se desarrolló, durante el siglo $\mathrm{XV}$, un activo distrito manufacturero centrado en la producción de paños de lana. En el área de las bailías de Ontinyent y Alcoi, junto al condado de Cocentaina, centenares de pelaires, tejedores, tundidores y tintoreros, junto a miles de trabajadores y trabajadoras a domicilio, elaboraban anualmente unos 8.000 paños que se comercializaban en todas las comarcas del centro-sur del reino de Valencia, y que viajaban incluso a ciertas zonas de Castilla. El éxito de estos tejidos se debía, en buena manera, a su estándar de calidad, ya que se trataba de paños amplios (de entre 1.800 y 2.100 hilos en su trama), que además pasaban por el batán, por el cardado a la percha, por el tundido y finalmente por la tintorería. Estos productos de calidad media-alta exigían lógicamente buenos coordinadores o gestores de los procesos técnicos. El recurso a la prosopografía nos ha permitido individualizar y detallar más de una decena de estos artesanos emprendores.

Nos centramos en una villa, Cocentaina (núcleo de tan solo quinientos fuegos), porque así es posible seguir a las familias y rastrear los profesionales para ofrecer una mayor precisión a la hora de catalogar y valorar los esfuerzos económicos, las actividades y los negocios. Lo que se deduce tras la observación de treinta años de secuencia documental y análisis prosopográficos (1470-1500) es que un reducido grupo de familias o linajes acaba controlando (y gestionando) los resortes necesarios para la producción de paños. Todo el «atrezo industrial», por utilizar la expresión de Panciera (los batanes, las tintorerías, los tiradores, las almazaras), el comercio de lana, de aceite y de tintes, las grandes cabañas de ganado ovino, están en manos de estas mismas familias que configuran las empresas amplias citadas. Nombres como los Borràs, Bosch, Calatayud, Estanya, Figuerola, Maiques, Martí, Pérez de Requena o Sanç, tienen bajo su gestión no sólo instalaciones y productos, también a otros artesanos dependientes o semidependientes, y a un gran número de trabajadoras y trabajadores auxiliares.

Debemos indicar que se trata de familias y linajes sólidos, que cuentan con numerosos profesionales del sector industrial y, en ocasiones, mercantil, que nos hablan de una vocación manufacturera enlazada de varias unidades de producción y de varias generaciones ${ }^{45}$. Pero la solidez no está sólo en el número de artesanos que acumula un

45 En los treinta años de seguimiento hemos documentado al menos, de cada linaje, cuatro representantes con oficio textil, y en ocasiones hasta nueve profesionales: cuatro los Estanya, Maiques y Pérez de Requena (que incluían pelaires, tundidores y pañeros); cinco los Sanç (que incluían además tejedores y tintoreros); 
linaje, sino lógicamente en los negocios desarrollados y en la capacidad y carácter de sus empresas. Por ejemplo, la familia Borràs contaba simultáneamente con tres pelaires, dos sastres y un tendero de paños; de ellos destacó Nicolau (documentado entre 14701488), un sastre que se convirtió en pañero (draper), y que encontramos comprando lana y productos para el tinte en villas alejadas e incluso en Valencia (donde contacta con grandes mercaderes italianos, como los della Chiesa), también ganado y carne; a su vez lo documentamos vendiendo paños tintados a pelaires de la comarca en un taller de su propiedad; pero además encarga el tintado de los paños que manda elaborar, y paga grandes cantidades a los profesionales locales por estas operaciones. El faciunt laborare, el trabajo por encargo aparece con claridad, como veremos también en muchos otros casos, por los compromisos que adquieren ambas partes antes notario, o por denuncias que se suscriben ante la justicia municipal.

El linaje de los Bosch nos ha permitido documentar tres pelaires, un tundidor, un tintorero y un pañero. Fue el pelaire Gabriel (1474-1502) el que configuró una importante empresa de gestión para la producción de paños, y hasta tal punto se especializó en su elaboración y venta que en la década de 1480 ya es catalogado como pañero; propietario de taller, de molino de aceite y de una botiga en la plaza del Mercado, también de cuatro parcelas de tierra y de una alquería con una decena de vasallos (era llamado «el señor de la alquería de Ares»); distribuía lana y mandaba hacer paños, vendía aceite al por mayor, también cabezas de ganado, carne y cereales de todo tipo, pero sobre todo paños que transportaba a comunidades y villas de las comarcas vecinas; su actuación en el mercado de paños era tan intensa que fue nombrado por el conde para gestionar el pago del impuesto general del Tall del Drap con sus arrendadores de Valencia; su hijo Joan (futuro tintorero) casó con la hija del tintorero más activo de la villa (Francesc de León) con dote elevada de 10.000 sueldos, mientras su hija Elionor contrajo matrimonio con un caballero local con dote de 18.000 sueldos; fue jurado, justicia y almotacén y arrendador de numerosos impuestos y derechos condales.

La familia Calatayud había desarrollado inicialmente vocación por el tintado, pero tras una generación redirigió sus intereses a la producción y venta de paños. Entre sus seis miembros encontramos a dos tintoreros de principio, y a cuatro pelaires y pañeros después. Jaume y Ginés, padre e hijo tintoreros, trabajaban en la tintorería del primero, pero a finales de la década de 1470, la familia vendió el casal a otro tintorero contestano. Joan (1471-1479), hermano de Ginés, desarrolla ya una empresa de producción y venta de paños sin llegar a ser nunca profesional del tintado: fue catalogado como pañero, y realizó una intensa política de adquisición patrimonial (compra un tirador de paños, el dominio directo de un molino harinero, que veremos convertirse años después en batán, y de un horno de pan, dos parcelas, una heredad, dos casas, un huerto y la vecina alquería de Benufit, que le suponía anualmente 1.000 sueldos de renta). Pero fue su hijo Joan, el menor (1471-1502), quien, a juzgar por su presencia en las fuentes, activó la empresa

seis los Borrás, Bosch y Calatayud; y hasta nueve los Figuerola y Martí, véase vol. II de nuestra tesis doctoral, LLIBRER, Industria textil y crecimiento regional, pp. 26-302. 
pañera de su padre: compra una casa que será su tienda en la villa; vende cerales en grandes cantidades (sólo el año 1480 distribuye más de 7.000 litros), también vino y aceite (más de 3.000 litros en un año), pero sobre todo, paños tintados cuyo mercado amplía hasta la ciudad de Xàtiva, $50 \mathrm{~km}$ al norte, o a Sax, a $60 \mathrm{~km}$ al sur; compra pastel ( $280 \mathrm{~kg}$. en menos de un año, y para estos negocios contacta con los Spannochi) que después distribuye entre tintoreros de la vecina Alcoi a quienes contratará para tintar sus paños (a 35 sueldos de media por pieza); pero su actividad de producción de paños es tan elevada que a mediados de la década de 1490 firma una compañía para el teñido de sus numerosos paños con un tintorero contestano; su patrimonio manifiesta también esta gestión de la producción textil: convierte en batán el molino harinero de su padre (en el año 1500), arrienda el tirador de paños, además adquiere otro molino harinero, una casa con huerto, y siete parcelas (viñas, olivares, moreral), compra tres esclavos y tiene siervienta en casa. Su hermano Onofre (1481-1504), también pañero, parece complementar la empresa de Joan: lo documentamos comprando anticipadamente lana al por mayor (contacta con ganaderos de comarcas vecinas y se asegura la materia prima: en dos meses de 1494 inverte 500 sueldos por $325 \mathrm{~kg}$ de lana), y la distribuye entre pelaires de la villa, de los que después recibirá paños; no obstante, su empresa de comercialización textil es tan activa que también compra grandes cantidades de paños a pelaires de Alcoi (en una sola transacción adquiere 25 unidades ya tintadas por 2.000 sueldos); testimonios de esta activa empresa son también el arrendamiento de otro batán (que le cuesta 660 sueldos anuales) y de dos almazaras (240 sueldos/año ${ }^{46}$.

La saga pañera de los Martí se remontaba a la década de 1420, donde localizamos al pelaire Jaume y al draper Pere (ambos en 1424). En la segunda mitad de la centuria se han constituido en una de las familias con empresas más amplias y con más presencia en las fuentes. Los hijos y nietos de Pere Martí, ganadero ovino, fueron seis pelaires, dos molineros y un draper, y de entre todos ellos destacó, sin duda, Bernat Martí (1470-1482). Este pelaire-tundidor configuró pronto una de las más destacadas empresas de gestión de la producción pañera: compraba lana a crédito a ganaderos musulmanes, que después redistribuía en pequeñas partidas a pelaires vecinos; a la vez lo documentamos vendiendo paños tintados y sin tintar por todas las comarcas del sur del reino; pero también se convierte en redistribuidor de todo tipo de productos agrícolas en la misma área, cereales, vino y, sobre todo, aceite (en sólo un día llega a vender 4.000 litros); en su casa tenía botiga, urdidor y tornos, que podía distribuir a trabajadoras vecinas; contacta con distintos tintoreros de la villa para que den color a sus paños, y tras el encargo de tales operaciones, paga a los profesionales (a media de 60 sueldos por paño); muy pronto descubre el mercado del crédito donde iba depositando parte de sus beneficios pañeros (suscribió 44 títulos que le exigieron una inversión de 25.580 sueldos, y que le suponían un beneficio anual de 2.300), como muchos de sus deudores eran artesanos del textil, es fácil deducir que esta dependencia

\footnotetext{
46 No olvidemos la necesidad de aceite en dos de los procesos de la elaboración pañera, de ahí la relación de todos estos empresarios con su producción y venta, LLIBRER, "L'inici de la vocació oleícola en època baixmedieval".
} 
nacía en la actividad pañera; la amplitud de su empresa se recogía en sus tres libros de cuentas (el de draperia, el dels tints y el dels censals) ${ }^{47}$.

El pelaire Jaume Moltó (1470-1505) muestra diversificación empresarial parecida: compra lana anticipadamente que después distribuirá a otros pelaires; también productos para el tinte; vende aceite, cereales y animales de tiro, pero sobre todo, paños, que llegan a Xixona o Elx ( $80 \mathrm{~km}$ al sur); y gestiona el trabajo textil de tundidores y tintoreros a los que encarga sus operaciones; y para complementar su empresa compra un tirador y un molino batán; como mano de obra auxiliar cuenta con mozos y esclavos. Otros ejemplos con similares negocios y estrategias son los de los también pelaires Joan Figuerola, Onofre Navarro, Pere Pérez de Requena o Antoni Sanç.

La iniciativa de estos artesanos de Cocentaina no es lógicamente una excepción, tales situaciones las encontramos en otras villas del área como Ontinyent, Alcoi o Bocairent con sus empresarios destacados ${ }^{48}$. Pero también en otras zonas rurales ya estudiadas y prosopografiadas, como el Palancia o la Plana de Castelló ${ }^{49}$. Es cierto que las fuentes no siempre aportan el detalle o el matiz adecuado para visualizar el carácter de estas tipologías empresariales, pero una lectura atenta sí nos acerca a tales negocios. Lo que sale pocas veces a la luz, lo que las fuentes silencian, es el rol de los artesanos dependientes o semidependientes que realizaban los encargos de los emprendedores donde había, seguro, infinidad de situaciones: dependencia coyuntural como trabajadores de fase, trabajo a cambio del suministro de inputs, relación como socio con el empresario...

\subsection{Empresas de manufactura centralizada}

Frente a la dispersión de núcleos de trabajo en diferentes fases técnicas deslocalizadas, en ciertos sectores productivos la necesidad obligaba a la concentración. La llamada manufactura centralizada implicaba empresas que necesitaban una única instalación fija y maquinaria con uso y supervisión del empresario y/o de los especialistas. La construcción naval, la minería y tratamiento de metales pesados, la construcción edilicia, la cerámica y el vidriado, la elaboración de obras artísticas (retablos, imaginería...). En ocasiones, la relación y las operaciones de los trabajadores implicados eran complejas y difíciles de precisar, de ahí la necesidad de un empresario coordinador. Sólo un ejemplo inicial clarificador que todavía es objeto de estudio: a la hora de fabricar un retablo, el juego y la diferenciación entre tallistas, mazoneros, escultores, pintores, entalladores o imagineros todavía nos resulta hoy difícil de $\operatorname{aclarar}^{50}$, y nos recuerda también el concurso de

\footnotetext{
47 Analizamos la empresa de este importante artesano en LLIBRER, "Artesanos emprendedores en la industria textil”, pp. 295-317.

48 Sobre estos otros ejemplos, LliBrer, "La configuración d'un districte industrial".

49 Aparici y NAVArro, "El libro memorial de la tutela del tejedor Joan Fretero"; NAVArro, "Joan Santalinia i altres paraires de Castelló"; NAVArro, "La industria textil en los reinos de Aragón y Valencia"; APARICI MArTí, "Capilaridad de la manufactura textil", pp. 181-199; ApARICI MARTí, "Paños, tintes y batanes", pp. 185-212.

50 Serra y Miquel, "La madera del retablo y sus maestros", pp. 13-37.
} 
maestros, profesionales, trabajadores auxiliares y asalariados con muy diversos niveles de especialización, y desigual grado de autonomía o dependencia; desde artesanos sin taller a peones, mozos, aprendices, asalariados, sirvientes..., todos reunidos en el espacio de producción, una suerte de «hacienda industrial», por seguir la denominación italiana, con trabajo y formas de remuneración muy diversas ${ }^{51}$. Y, como en el caso empresarial anterior, los gestores de tales modelos de producción podían ser artesanos emprendedores del mismo sector. En todo caso, sería un error ver tal solución empresarial como el antecendente del sistema de fábrica contemporáneo ${ }^{52}$. Un acercamiento a la industria cerámica, doméstica y de lujo, que llevamos algunos años estudiando, nos permitirá mostrar cómo funcionan estas empresas de ciclo continuo o centralizado.

A una decena de kilómetros de la ciudad de Valencia, se consolidaron, desde época islámica, diversas comunidades alfareras en pequeñas villas rurales que no superaban los 300 fuegos $^{53}$. Manises, Paterna o Mislata llegaron a desarrollar en el siglo XV un potente sector de producción seriada de cerámica doméstica y de lujo, y de complementos para la construcción (azulejos, tejas, pavimentos de representación) con destino al mercado de la capital, e incluso a la exportación. Decenas de hornos de cocción funcionaban en estas pequeñas villas con todas sus instalaciones auxiliares (talleres o palaus, edificios de almacenaje, patios de depósito, grandes balsas de decantación, botigas o tiendas especializadas). La cantidad de operaciones necesarias a la producción multiplicaban los trabajadores, pero las especificidades morfológicas, funcionales y estilístico-decorativas obligaban a un constante reciclaje técnico y a nuevas competencias dentro del taller (nuevos diseños, nuevos pigmentos, nuevas materias primas) ${ }^{54}$. La producción para el mercado, y con demandas altamente cambiantes, llevaba a la realización de encargos coyunturales de centenares o miles de piezas en poco tiempo, lo que agudizaba las necesidades de concentración de esfuerzos y de gestión. La documentación nos detalla además que para tales procesos de producción eran necesarias diversas instalaciones ubicadas en un mismo espacio, contiguas, para propiciar la efectividad y la rapidez operativa: en primer lugar el taller de elaboración, con distintas habitaciones para los tornos (siempre de tres a cinco), y otras para las piletas con la arcilla ya preparada para el suministro constante de los alfareros; un espacio abierto o patio donde había grandes balsas y pudrideros de decantación para preparar la materia prima (la arcilla debía mezclarse con arenas, calcita y agua); junto al patio eran necesarias otras zonas cubiertas de depósito y almacenaje de instrumental y piezas (y pensemos que algunas podían ser de gran tamaño con capacidades para centenares de litros); finalmente todo

\footnotetext{
51 Características del modelo, Franceschi, "Il mondo della produzione", pp. 400-417; MocAReLLI, "Fare impresa in età preindustriale", pp. 209-227.

52 Sobre estas erróneas tentaciones, Malanima, “Tipi d'impresa”, pp. 159-175.

53 López Elum, Pedro, Los orígenes de la cerámica de Manises y Paterna; NArbona, "Competencia, conflicto y violencia en la manufactura cerámica valenciana”, pp. 45-60.

54 CARoscio, "Tecnologia della produzione ceramica", pp. 425-450; CAROSCIO, La maiolica in Toscana tra medioevo e Rinascimento, pp. 39-56; GüLL, "L'artigianato della ceramica”, pp. 345-357; GüLL, L'industrie du quotidien; VILLANUEVA, "Actividad alfarera en el Valladolid bajomedieval".
} 
giraba alrededor del horno de cocción (o varios hornos) con la estructura y la amplitud necesaria para manipular y preparar hornadas de miles de piezas a la vez ${ }^{55}$.

Elaborar escudillas pintadas o grandes jarras de aceite, losas de pavimento policromadas o azulejos con iconografías suponía un proceso técnico que tal vez no se ha valorado lo suficiente. Pensemos que implicaba hasta diecisiete operaciones distintas, desde el aprovisionamiento de las materias primas hasta el embalaje de las piezas y su traslado a la ciudad ${ }^{56}$. Algunas de las actividades, muy intensivas en trabajo, demandaban un buen número de peones auxiliares, las más técnicas (trabajo en tornos, mezclas de los pigmentos, iconografía, cocción) reclamaban profesionales con importante cualificación; unas y otras, solicitaban el concurso del empresario-gestor-coordinador en el entorno laboral y en las instalaciones citadas.

El análisis de los contratos de obra de terra nos acerca a la praxis de estas empresas de esfuerzos laborales y técnicos concentrados. Pensemos que debían llevarse a cabo en muy poco tiempo (de un par de semanas a dos-tres meses), encargos de centenares y hasta miles de piezas, que no sólo debían ser elaboradas sino también adecuadamente embaladas. Estos contratos -en el fondo también trabajos por encargo-, nacían en mayor medida del sector mercantil urbano que adelantaba parte del capital pero que especificaba exigencias al productor. A partir de ese momento, la maquinaria se ponía en marcha, el empresario - un maestro ceramista (magister operis terre) o también un tendero del sector (botiguerius operis terre), de origen local-, concentraba en sus instalaciones al conjunto de trabajadores necesarios. Con alfares de entre tres y cinco tornos, y con la necesidad de completar encargos, en poco tiempo, de tan amplio volumen -recordemos que en estos se contabilizaba por grosses (unidad que refería a doce docenas $)^{57}$, podemos calcular la acumulación de entre una docena o una quincena de operarios, o tal vez más, reunidos en el amplio taller cerámico.

No es fácil reconstruir las condiciones en las que permanecían los alfareros especializados que trabajaban en los tornos, o los que pintaban las piezas, o los responsables de la cocción, o los auxiliares que preparaban la arcilla o que embalaban las piezas, la documentación prácticamente nada dice de tales situaciones. Se pueden intuir procesos de dependencia o semidependencia, incluso de salarización, pero también de participación comunada o societaria a juzgar por las numerosas compañías suscritas por varios artesanos o maestros, y a juzgar también por la frecuente propiedad mancomunada de la instalación clave, los

\footnotetext{
55 El conjunto de instalaciones era tan amplio que, normalmente, se habla, en plural, de obradores, y de sus numerosos espacios contiguos: uns obradors situats en les olleries majors de la dita vila [Paterna], e són cinc cases contigues ab mig forn de coure gerres majors, confrontats los dits obradors ab sèquia de Muncada, Llibrer, "Obradors, palaus i forns", pp. 240-241.

56 El detalle sobre los procesos técnicos, LLIBRER, "Relaciones protoindustriales en la producción cerámica", pp. 214-240.

57 Son frecuentes los encargos de 300, 400 ó 500 grandes tinajas en uno o dos meses; también de 2.000, 3.000 o hasta 4.000 piezas como escudillas, tarros de botica o tarros de azúcar para trapiches; o si hablamos de azulejos o losas de pavimento, las cantidades ascienden hasta las 12.000 o 13.000 piezas. Ejemplos de todos ellos en LlibreR, "Relacions protoindustriales en la producción cerámica", pp. 227-229.
} 
hornos de cocción ${ }^{58}$. Incluso las situaciones podían ser coyunturales, y el paso de una condición a otra podía producirse en función de los ritmos de la demanda o de las personalizaciones de las piezas a realizar. Los análisis prosopográficos nos permiten acercarnos a un buen número de maestros y artesanos, y de variadas especialidades, pero no es fácil acceder a las formas de remuneración ni a las relaciones de producción generadas.

El perfil económico del empresario se dibuja, eso sí, con nitidez, y son numerosos los casos que podemos aportar. Nos centraremos también en una comunidad, la pequeña Paterna de 200 casas a principios del siglo XV. Pasqual Sancho, magister operis terre de Paterna (1405), disponía de todos los instrumentos de trabajo necesarios para el tratamiento de la arcilla, cinco parcelas donde abastecerse, tenía en casa obra cerámica en stock (18 grandes tinajas llenas de obra de Malequa), y seis inmuebles industriales (unos obradores formados por cinco casas contiguas y además medio horno de cocción que compartía con otro maestro) ${ }^{59}$. Joan Benet (1403-1405), maestro vecino, era propietario de dos hornos, uno mayor para la cocción de piezas de gran volumen, y otro menor, además de un patio contiguo a ambos. Bernat Alcodorí (1403), maestro ceramista de la misma villa, tenía varios talleres contiguos (formados por tres casas con tres portales), un gran patio en el que disponía de un horno y de un almacén. Gil Salvador, alfarero de Paterna, era propietario de, al menos, tres obradores, de un horno pequeño y dos patios. García Alafzar, obrer de terra paternero también de principios del siglo XV, disponía de todo tipo de herramientas, de siete parcelas de tierra muy cercanas a la villa, de unos almacenes (uns palaus), de un horno con un patio contiguo, de la mitad de otro horno y de varios obradores.

La realizacón de los análisis prospográficos en una comunidad tan pequeña como la Paterna de inicios del Cuatrocientos permite observar dos detalles clave: por un lado, el destacado proceso de concentración de estas instalaciones productivas en muy pocas manos, en muy pocas empresas de gestión (son muy pocas las familias, que llegan a esta gestión y a esta propiedad, y que tienen la capacidad de invertir en estas costosas infraestructuras). A su vez, podemos deducir que el aumento de la producción cerámica, y la posibilidad de satisfacer la exigente y constante demanda mercantil urbana era posible precisamente no por la multiplicación de pequeños talleres familiares autónomos, sino por la confirmación de esos procesos de concentración de la propducción, de la gestión o del sistema gerencial.

\section{Conclusiones de un trabajo inicial}

El desarrollo teórico que hemos trazado, así como los ejemplos citados, junto a los trabajos de otros autores, nos permiten ya ciertas conclusiones iniciales. En primer lugar, nos hablan de la importancia de las actividades manufactureras en el mundo rural y, sobre todo, de su importante peso en las economías locales y en la intensidad

\footnotetext{
58 Llibrer, "Obradors, palaus i forns", pp. 235-241.

59 Los detalles de estos empresarios en LliBRER, "Obradors, palaus i forns", pp. 241-254.
} 
de la ocupación de su población activa en diferentes grupos y rangos de edad. En segundo lugar, toda esta iniciativa artesanal - que afectaba a sectores muy diversos, no sólo al textil- se traducía en una amplia variedad de soluciones organizativas atendiendo a diversos parámetros (tecnología, ciclo productivo, saber técnico, inputs y outputs, mercado, ritmos de la demanda...). A su vez, la acción combinada de todos estos condicionantes tendía a marcar las características de las empresas artesanales en dirección a tres puntos clave: la configuración de grupos de artesanos emprendedores (que asumían la iniciativa de gestión, y el rol de coordinación técnica del total o de parte de los procesos productivos); la relación cada vez más intensa entre este sector emprendedor y el mercado en la medida que dicho sector emprendedor no sólo se acercaba al mercado de forma directa para la adquisición de los inputs necesarios para su producción industrial, también para la venta de sus bienes finales, e incluso para asumir el mercado como una estrategia más de negocio (no es casual que estos empresarios manufactureros se dedicaran a la comercialización de otros productos o bienes de consumo), y que llegaran incluso a reorientar el peso de su línea estratégica hacia el mercado; también marcaba esta activa industria rural la configuración de un colectivo ampliamente plural de mano de obra, con distintos niveles de especialización, de salarización, de dependencia y de ocupación sectorial (donde el juego de la pluriactividad podía ser importante). Pensábamos que sólo el mundo urbano generaba tales jerarquías y características, pero el dinamismo de pequeñas villas traduce ya tal diversidad; y a su vez, nos permite recordar que la propiedad de los medios de producción y/o del producto comercializable no pueden ser los únicos elementos que determinen o condicionen el desarrollo manufactuero.

Entendemos que el concepto «empresa» permite, por ello, resaltar la complejidad de las distintas formas de producción, de las jerarquías laborales, de los grados tecnológicos, de las vías de negocio, de las estrategias de gestión, y de las redes que se tejían entre artesanos, mercaderes, inversores de todo tipo y clientes. El análisis prosopográfico permite una detallada reconstrucción de tales parámetros $\mathrm{y}$, sobre todo, de los flujos de capital que nutrían esta manufactura rural en crecimiento. Capital e iniciativa que, como hemos visto, procedían no exclusivamente del sector mercantil sino también del mismo sector de la producción, de los mismos artesanos, cuyo emprendimiento no sólo dinamizaba la manufactura mediante la aportación de capital, también mediante su conocimiento técnico de las fases productivas que le facilitaban iniciar el ciclo de elaboración y su misma gestión o coordinación. En una coyuntura y en un espacio rural donde la regulación de los oficios todavía era muy limitada, o en ocasiones inexistente, estos artesanos emprendedores tenían la capacidad de acceder a recursos laborales dispersos y diversos, a una mano de obra todavía no regulada por separaciones ni jerarquías claras pero de enorme potencial, y con la que se podían configurar interesantes redes de trabajo, colaboración y producción. Las diferentes formas empresariales descritas, y documentadas en el mundo rural bajomedieval, son precisamente reflejo de estas redes y relaciones, de la complejidad de los elementos y de los operadores en juego; pero una lectura superficial de tales tipologías puede llevarnos a una visión y a una conclusión postivista en el sentido de creer en una 
supuesta evolución de los modelos de gestión empresarial -del más simple al más complejo-, aunque en realidad las diversas soluciones organizativas adoptadas no representaban una sucesión de estados por las que se pasaba de modo secuencial, de la más sencilla a la más articulada, sino que era precisamente la coexistencia de las diversas opciones lo más representativo, como demuestran las fuentes y los estudios de caso ya citados: decenas de talleres de artesanos «independientes» convivían con centenares de trabajadores a domicilio, y también con mayores empresas centradas que aglutinaban diversas instalaciones, medios técnicos y profesionales. Esta presencia sincrónica de modelos permitía, en ocasiones, compartir, según ritmos de demanda y exigencias del mercado, mano de obra, saber técnico e instalaciones, de modo que un artesano o un trabajador auxiliar podía encuadrarse en uno u otro sistema atendiendo a distintas coyunturas.

Y este juego de posibilidades no hace sino recordar que estas empresas manufactureras bajomedievales debían enfrentarse, más allá de tipos y modelos, como recuerda Verna, a la gestión de cuatro puntos clave: la gestión del ciclo productivo (acceso a materias primas, tecnología, fuentes de energía...); la gestión de la mano de obra (especialización, jerarquía, ritmos de trabajo, remuneraciones, dependencias); la gestión de las relaciones con el mercado (circulación de productos, conocimiento de la demanda, estándar de calidades, fijación de precios, transporte); y la gestión de la financiación y de sus formas (origen del capital, tanto de la esfera mercantil como de la misma producción; relación con el negocio agrícola; formación de compañías de capital y trabajo, atracción de inversores ajenos a la producción, mercado del crédito, etc.). Y hacia estos cuatro puntos es hacia donde, tal vez, deben circular en un futuro las investigaciones sobre este dinámico mundo de la manufactura rural que hoy estamos comenzando a descubrir.

\section{Bibliografía citada}

Ammannati, Francesco, "L'opifici lanieri di Francesco di Marco Datini", Giampiero Nigro (ed.), Francesco di Marco Datini. L'uomo, il mercante, Fondazione Datini, Florencia, pp. 497-523.

Aparici MarTí, Joaquín, Producció manufacturera i comerç a Vila-real (1360-1529), Ajuntament de Vila-real, 1996.

APARICI MARTí, Joaquín, Manufacturas rurales y comercio interior valenciano. Segorbe en el siglo $X V$, Universitat de Castelló, 1998.

Aparici Martí, Joaquín, El Alto Palancia como polo de desarrollo económico. El sector de la manufactura textil, Ajuntament de Sogorb, 2001.

Aparici MarTí, Joaquín, "Emigración y trabajo en el siglo XV. Los artesanos del barro en la Plana", En VI Congrés d'Història i Filologia de la Plana, Castelló, 2001, pp. 299-322. APARICI MARTí, Joaquín, "La promoció social dels artesans: els treballadors del cuiro al Castelló medieval", En VI Congrés d'Història i Filologia de la Plana, Castelló, 2001, pp. 323-350. 
ApARICI MARTí, Joaquín, "Pieles, zapateros, curtidurías. El trabajo del cuero en la zona septentrional del reino de Valencia (ss. XIII-XV)", Millars: espai i història, 35 (2012), pp. 49-68.

ApARICI MARTí, Joaquín, "Paños, tintes y batanes: mapa de la producción textil medieval en la zona septentrional del Reino de Valencia", Boletín de la Sociedad Castellonense de Cultura, 86 (2010), pp. 185-212.

ApArici MARTí, Joaquín, “Capilaridad de la manufactura textil en la Plana de Castelló. El caso de Onda en el siglo XV”, Anuario de Estudios Medievales, 40-1 (2010), pp. 181-199.

APARICI MARTí, Joaquín, "Manufactures rurals mudèjars en terres de l'interior del nord de València”, Berenguer, Ernest (ed.), Ferran II i la Corona d'Aragó. Institut d'Estudis Catalans, Barcelona, 2018, pp. 267-284.

Aparici, Joaquín y Navarro, Germán, "El libro memorial de la tutela del tejedor Joan Fretero (Segorbe, 1432-1440)", Estudis Castellonencs, 7, pp. 231-264.

BARlucchi, Andrea, "Industria e artigianato nelle aree extraurbane", Storia del lavoro in Italia. Il Medioevo, Castelvecchi, Roma, 2017, pp. 246-280.

Bernard, Philippe, Maître, valet et apprenti au Moyen Âge. Essau sur une production bien ordonnée, CNRS, Toulouse, 2009.

Bonachía, Juan A. y Carvajal, David (eds.), Los negocios del hombre. Comercio y rentas en Castilla, Valladolid, 2012.

Braunstein, Philippe, "Les métiers du métal. Travail et entreprise à la fin du Moyen Âge", P. Lambrechts y J.P. Sosson (eds.), Les métiers au Moyen Âge. Aspects économiques et sociaux, Lovaina, 1994, pp. 23-52.

BraunsteIn, Philippe, “Artesano”, Diccionario razonado del Occidente Medieval, Akal, Madrid, 2003, pp. 65-68.

Braunstein, Philippe, Travail et entreprise au Moyen Âge, De Boeck, Bruselas, 2003.

CARACAUSI, Andrea, "Mercanti e manifatture tessili fra Padova e Venezia. Reti di scambio e specializzazioni produttive in età moderna", Le reti dello scambio. Uomini, merchi, architetture (XV-XIX sec.), Bulzoni, Roma, 2010, pp. 19-31.

Caracausi, Andrea, "Tipos de empresa en el periodo preindustrial", Debates. Red de Estudios de Historia de Empresas, 23 (2016), pp. 2-9.

Caracausi, Andrea; Davies, Matthew; Mocarelli, Luca (eds.), Between Regulation and Freedom. Work and Manufactures in European Cities, 14th-18th Centuries, Cambrigde Publishing, 2018.

CARrÉre, Claude, "Structures et évolution des entreprises pré-industrielles: le cas de Barcelone au bas Moyen-Age", Studi in Memoria di Federigo Melis 3, Nápoles, 1978, pp. 37-57.

CóRdoba de la Llave, Ricardo, Los oficios medievales.Tecnología, producción y trabajo. Madrid, Síntesis. 
Córdoba de la Llave, Ricardo, "Industria y artesanía rural en la Corona de Castilla a fines de la Edad Media", Germán Navarro y Concepción Villanueva (coords.), Industrias y mercados rurales en los reinos hispánicos (siglos XIII-XV), SEEM, Murcia, 2017, pp. 37-62.

Caroscio, Marta, La maiolica in Toscana tra Medioevo e Rinascimento, Florencia, 2009.

CAroscio, Marta, "Tecnologia della produzione ceramica in area valenciana: da al-Andalus al periodo mudéjar", Archeologia Medievale, 40 (2012), pp. 425-450.

Chandler, Alfred, La mano visible. La revolución de la dirección en la empresa norteamericana, 1987.

Degrassi, Donata, L'economia artigiana nell'Italia medievale, Carocci, Roma, 1998.

Demo, Edoardo, L'anima delle città. L'industria tessile a Verona e Vicenza (1400-1550), Unicopli, Milán, 2001.

EsPINAs, Georges, Sire Jehan Boinebroke, patricien et drapier douaisien, Raoust, Lille, 1933.

FAVEro, Giovanni, "Microstoria e storia economica", Paolo Lanaro (ed.), Microstoria. A venticinque anni de l'Eredità immateriale, Milán, 2011, pp. 107-117.

FrANCESCHI, Franco, "L'impresa mercantile-industriale nella Toscana del secoli XIVXV”, Annali di Storia dell'impresa, 14 (2003), pp. 229-249.

FrANCESCHI, Franco, "Il mondo della produzione: artigiani, salariati, Corporazioni", Storia del lavoro in Italia. Il Medioevo, Castelvecchi, Roma, 2017, pp. 374-377.

García Marsilla, JuAn V. e IzQuierdo Aranda, Teresa, Abastecer la obra gótica. El mercado de materiales de construcción y la ordenación del territorio en la Valencia bajomedieval, Generalitat, Valencia, 2013.

GüLl, Paolo, "L'artigianato della ceramica tra Piamonte e Provenza alla fine del medioevo. Qualche riflessione”, Bollettino Storico-Bibliografico Subalpino, 94 (1996), pp. 345-357.

Güll, Paolo, L'industrie du quotidien: production, importations et consommation de la cerámique à Rome entre XIVe et XVIe siècle, École Française, Roma, 2003.

Hinojosa, José, "La industria de Elche a fines de la Edad Media”, IX Jornades d'Estudis Locals, Mallorca, pp. 83-97.

Hinojosa, José, "El trabajo mudéjar en la Valencia medieval", IV Simposio Internacional de Mudejarismo, Teruel, pp. 57-82.

Hunt, Edwin, The Medieval Super-Companies. A Study of the Peruzzi Company of Florence, Cambridge, Cambridge UP, 1997.

Igual, David y NaVArro, Germán, “Artesanos y mercaderes. De la producción manufacturera al comercio”, Historia de Castellón, vol I, Castelló, 1993, pp. 250-255. 
Igual, David; Llibrer, Antoni, NAvarro, Germán, "Materias primas y manufacturas textiles en las aljamas rurales valencianas en la baja Edad Media", VI Simposio Internacional de Mudejarismo, Teruel, pp. 311-327.

IRADIEL, Paulino, Evolución de la industria textil castellana en los siglos XIII-XVI. Factores de desarrollo, organización y costes de la producción manufacturera en Cuenca. Univ. Salamanca, 1974.

IRADIEL, Paulino, "Familia y función económica de la mujer en actividades no agrarias", La condición de la mujer en la Edad Media, Madrid, Universidad Complutense, 1986, pp. 223-259.

IrADIEL, Paulino, "En el Mediterráneo occidental peninsular. Dominantes y periferias dominadas en la baja Edad Media”, Áreas. Revista de Ciencias Sociales, 8, pp. 64-76. IrAdiel, Paulino, et alii, Oficios artesanales y comercio en Castelló de la Plana (13711527), Fundació Dávalos, Castelló, 1993.

Iradiel, Paulino, "Ciudades, comercio y economía artesana", XXV Semana de Estudios Medievales, Pamplona, 1999, pp. 603-658.

IradiEL, Paulino, "Metrópolis y hombres de negocios (siglos XIV y XV)", XXIX Semana de Estudios Medievales, Pamplona, 2003, pp. 277-310.

IRADIEL, Paulino, "Fuentes de derecho privado: protocolos notariales e historia económica", Francesco Ammannatti (ed.), Dove va la Storia Economica? Metodi e prospettive, secc. XIII-XVIII, Florencia, 2011, pp. 225-247.

LANARO, Paola, "Il mercante e l'imprenditore: l'evoluzione storica attraverso il lessico", Annali di Storia dell'Impresa, 18 (2007), pp. 209-216.

Llibrer, Antoni, Godella, una comunidad rural en la baja Edad Media, Ajuntament de Godella, Valencia, 1996.

Llibrer, Antoni, "La formación de compañías para el tintado de paños. El caso de Cocentaina en el siglo XV", Anuario de Estudios Medievales, 41/1 (2011), pp. 59-72.

Llibrer, Antoni, "La configuració d'un districte industrial a la baixa Edad Mitjana. Les viles draperes de la Vall d'Albaida, l'Alcoià i el Comtat", Recerques: Història, Economia, Cultura, 64, 2013, pp. 5-31.

LliBrer, Antoni, “Artesanos emprendedores en la industria textil. Del taller al mercado: el caso del pelaire contestano Bernat Martí (1469-1482)", En la España Medieval, 37 (2014), pp. 295-317.

Llibrer, Antoni, Industria textil y crecimiento regional: la Vall d'Albaida y el Comtat durante el siglo $X V$. Universitat de València, 2014.

Llibrer, Antoni, "Dualidad en la aljama. Propietarios de tierra y hombres de negocio musulmanes. El caso de la comarca valenciana de El Comtat (seguna mitad del siglo XV)", Anaquel de Estudios árabes, 25, 2014, pp. 45-75.

LliBrer, Antoni, "Relaciones protoindustriales en la producción cerámica. Manises y Paterna en la segunda mitad del siglo XV", Medievalismo, 24 (2014), pp. 214-240. 
LliBrer, Antoni, "Llana, ramat i oli. Empreses en època medieval: nivell d'inversió i costos a la draperia (el Comtat al segle XV)”, Saitabi, 65 (2015), pp. 63-79.

Llibrer, Antoni, "Empreses i empresaris en àmbit rural. Sectors i sistemes de gestió. Exemples del País Valencià (segles XV)", Identidades urbanas Corona de Aragón-Italia (siglos XIV-XV), Univ. de Zaragoza, 2016, pp. 61-74.

LliBrer, Antoni, "Obradors, palaus i forns. Infraestructura, costes y praxis manufacturera en la cerámica: Paterna (1403-1405)”, El País Valenciano en la baja Edad Media. Estudios dedicados al profesor Paulino Iradiel, PUV, Valencia, 2018, pp. 233-256.

Llibrer, Antoni, "L’inici de la vocació oleícola en època baixmedieval. Producció, comerç i tecnologia", Afers. Fulls de recerca i pensament, 94 (2020), en prensa.

López Elum, Pedro, Los orígenes de la cerámica de Manises y Paterna (1285-1335), Ed. Federico Doménech, Valencia, 1984.

Malanima, Paolo, “Tipi d'impresa prima della crescita moderna", Annali di Storia dell'Impresa, 14 (2003), pp. 159-175.

Martínez Araque, Iván, En els orígens de la indústria rural. L’artesanat a Alzira i la Ribera en els segles XIII-XV, Univ. de València, 2012.

Menjot, Denis, "El mundo del artesanado y la industria en las ciudades de Europa Occidental durante la Edad Media (siglos XII-XV)", Catharum, 11 (2010), pp. 5-18.

Mocarelli, Luca, "Fare impresa in età preindustriale: reflessioni a partire dal caso lombardo (secolo XVIII)", Roberto Leggero (ed.), Lavoro e impresa nelle società preindustriali, Mendrisio, 2017, pp. 209-227.

Montero, Encarna, "Moro Petit: los trabajos de un picapedrero musulmán en una ciudad militantemente cristiana (Valencia, 1407-1440)", Saitabi, 66 (2016), pp. 27-39.

Narbona, Rafael, "Competencia, conflicto y violencia en la manufactura cerámica valenciana del siglo XV", Identidades Urbanas Corona de Aragón-Italia, Valencia, pp. 45-60.

Navarro Espinach, Germán, "Joan Santalínia i altres paraires de Castelló a la fi del segle XV, V Congrés d'Història i Filologia de la Plana, 1998, pp. 155-178.

NAVARro EsPinAch, Germán, "Los negocios de la burguesía en la industria precapitalista valenciana en los siglos XIV-XVI", Revista d'Història Medieval, 11, 2000, pp. 67-104.

Navarro Espinach, Germán, "La industria del cuero en el Reino de Valencia y en el concejo de Teruel (siglos XIII-XVI)", Mil años de trabajo del cuero. II Simposio de Historia de las técnicas, Córdoba, 2003, pp. 201-230.

Navarro Espinach, Germán, "La industria textil en los reinos de Aragón y Valencia en la Edad Media", XVII Congreso de Historia de la Corona de Aragón, vol. I, 2003, pp. 475-492.

NAVARro Espinach, Germán, "La industria de la construcción en los países de la Corona de Aragón (siglos XIII-XVI)", Cavaciocchi, S. (ed.), L'edilizia prima della Rivoluzione Industriale, XXXVI Settimana di Studi i Prato, Florencia, 2003, pp. 167-208. 
Navarro Espinach, Germán, "Estudios sobre industria y artesanado en la España medieval", Actas y Comunicaciones del Instituto de Historia Antigua y Medieval, 8 (2012), pp. 2-10.

Navarro Espinach, Germán, "Les industries rurales dans la Couronne d'Aragon au XVe siècle", Les industries rurales dans l'Europe médiévale et moderne, Toulouse, 2013, pp. 89-112.

Navarro Espinach, Germán, "Los sectores punta de la industria rural en la Corona de Aragón: azúcar, textil y otros”, Germán Navarro y Concepción Villanueva (coords.), Industrias y mercados rurales en los reinos hispánicos (siglos XIII-XV), SEEM, Murcia, 2017, pp. 175-200.

Pelet, Paul-Louis, "Une industrie bimillénaire: la sidérurgie du Jura vaudois", Annales ESC, 29-4 (1974), pp. 789-812.

Pfirsch, Thomas, “Artisans et pluriactivité. L'exemple de Dijon à la fin du Moyen Âge”, Historie Urbaine, 6 (2002), pp. 5-22.

Poussou, Jean-Pierre, "Les industries rurales dans le sud-ouest de la France au XVIIIe siècle", Les industries rurales dans l'Europe médiévale et moderne, Toulouse, 2013, pp. 223-244.

PrATESI, Stefano, "Il lavoro contrattato e la nascita delle professioni nel basso medievo", Tesi di Laurea, Univ. De Florencia, 2016.

Ruiz Martín, Felipe, Los alumbres españoles. Un índice de la coyuntura económica europea en el siglo XVI, Madrid, Univ. Autónoma, 2005.

Scherman, Matthieu, Familles et travail à Trévise à la fin du Moyen Âge (vers 1434vers 1509), EFR, Roma, 2013.

Serra, Amadeo y Miquel Matilde, "La madera del retablo y sus maestros. Talla y soporte en los retablos medievales valencianos", Archivo de Arte Valenciano, 91 (2010), pp. 13-37.

Serrano, Joaquim, “Desencolupament i destrucció d'una minoria: els moriscos al senyoriu d'Elx”, Recerques 27 (1993), pp. 62-72.

SiCARD, Germain, Aux origines des sociétés anonymes. Les moulins de Toulouse au Moyen Age, Armand Colin, París, 1953.

TiLly, Charles, "Flows of capital and forms of industry in Europe, 1500-1900", Theory and Society, 12 (1983), pp.123-143.

VERnA, Catherine, "Quelles sources pour quelles entreprises du XIIIe au XVe siècle", Francesco Ammannatti (ed.), Dove va la Storia Economica? Metodi e prospettive, secc. XIII-XVIII, Florencia, 2011, pp. 339-372.

Verna, Catherine, "Elites rurales, industries et fortune (Catalogne, Vallespir, XIVeXVe Siècle)", Élites rurales méditerranéennes au Moyen Âge, Mélanges de l'École francaise de Rome, 124 (2012), pp. 461-478. 
Verna, Catherine, "Pour une approche biographique des entrepreneurs des campagnes médievales", Les industries rurales dans l'Europe médiévale et moderne, Toulouse, 2013, pp. 77-88.

Verna, Catherine, "Entreprises rurales en Méditerranée occidentale (XIIIe-XVe siècles). Un programme collectif de Recherche", Germán Navarro y Concepción Villanueva (coords.), Industrias y mercados rurales en los reinos hispánicos (siglos XIII-XV), Editum-SEEM, Murcia, 2017, pp. 203-220.

Verna, Catherine, L'industrie au village. Essai de micro-histoire (Arles-sur-Tech, XIVe et Xve siècles), Belles Letres, París, 2017.

Villanueva, Olatz, Actividad alfarera en el Valladolid bajomedieval, Valladolid, Universidad de Valladolid, 1998.

ZANOBOni, Paola, "De suo labore et mercede me adiuvavit. La manodopera femminile a Milano nell'età sforzesca”, Nuova Rivista Storica, 78/1, pp. 103-121. 
